\title{
Scale-dependent environmental filtering of ground-dwelling predators in winter wheat and adjacent set-aside areas in Hungary
}

\author{
Jana Růžičková ${ }^{1}$ (D) Ferenc Kádár ${ }^{2}$ - Ottó Szalkovszki ${ }^{3}$. Anikó Kovács-Hostyánszki ${ }^{4} \cdot$ András Báldi $^{4,5} \cdot$ Zoltán Elek $^{1}$
}

Received: 5 September 2019 / Accepted: 6 June 2020 / Published online: 14 June 2020

(c) The Author(s) 2020

\begin{abstract}
Agricultural intensification may act as an environmental filter shaping invertebrate assemblages at multiple spatial scales. However, it is not fully understood which scale is the most influential. Therefore, we utilized a hierarchical approach to examine the effect of local management (inorganic fertilization and soil properties; within-field scale), habitat type (winter wheat field and set-aside field; between-field scale) and landscape complexity (landscape scale) on assemblage structure and functional diversity of two important groups of natural enemies, carabids and spiders, in a cultivated lowland landscape in Hungary. Environmental filtering affected natural enemies at different spatial scales; likely as a result of enemies' different dispersal ability and sensitivity to fertilizer use. Carabids were strongly affected at the within-field scale: positively by soil $\mathrm{pH}$, negatively by soil organic matter and fertilization. At the between-field scale, carabids had higher activity density in the set-aside fields than in the winter wheat fields and simple landscapes enhanced carabids diversity, species richness and activity density at the landscape scale. Spiders were more abundant and species-rich in the set-aside fields than in the winter wheat fields. Although highly mobile (macropterous) carabids might disperse to arable crops from greater distances, while spiders possibly depended more on the proximity of set-aside fields, the winter wheat fields (where pest control should be delivered) were utilized mostly by common agrobiont species. Increasing crop heterogeneity within arable fields could be a potential option to increase the diversity of carabids and spiders in the studied region.
\end{abstract}

Keywords Carabids $\cdot$ Ecological intensification $\cdot$ Fertilizer $\cdot$ Landscape complexity $\cdot$ Natural pest control $\cdot$ Spiders

Electronic supplementary material The online version of this article (doi:https://doi.org/10.1007/s10841-020-00249-9) contains supplementary material, which is available to authorized users.

Jana Růžičková

jr.tracey@seznam.cz

1 MTA-ELTE-MTM Ecology Research Group, Biological Institute, Eötvös Loránd University, Pázmány Péter sétány 1/C, Budapest 1117, Hungary

2 Centre for Agricultural Research, Plant Protection Institute, Herman Ottó út 15, Budapest 1022, Hungary

3 Department of Botany, Institute for Plant Diversity, Külsőmező út 15, Tápiószele 2766, Hungary

4 Centre for Ecological Research, Institute of Ecology and Botany, Lendület Ecosystem Services Research Group, Alkotmány utca 2-4, Vácrátót 2163, Hungary

5 Centre for Ecological Research, GINOP Sustainable Ecosystems Group, Klebelsberg Kuno utca 3, Tihany 8237, Hungary

\section{Introduction}

Reduced landscape heterogeneity, as a result of progressive agricultural intensification, is the major driver of biodiversity loss in many countries across Europe (Kleijn et al. 2009; Fahrig et al. 2011). It also acts as an environmental filter (Duflot et al. 2014; Gámez-Virués et al. 2015) that reduces the capacity of landscapes to support large species-pools of arthropods (Ewers and Didham 2006; Hendrickx et al. 2007; Tscharntke et al. 2012). Environmental filtering increases a particular kind of species turnover when the most specialized species are replaced with generalist ones (biotic homogenization: Olden et al. 2004; Clavel et al. 2011; Duflot et al. 2014; Gámez-Virués et al. 2015). Such homogenized assemblages in the ecosystem can provide a limited range of ecosystem services due to their reduced functional diversity (Olden et al. 2004; Cadotte and Tucker 2017). Since these species share the same generalized traits, some resources may become inaccessible, while competition for another set of resources will increase. Additionally, more specialized 
arthropods with low dispersal ability cannot reach complementary resources and they are out-competed by more mobile species (Hendrickx et al. 2007; Tscharntke et al. 2012).

Environmental filtering caused by agricultural intensification has multiple components and affects arthropod assemblages at different spatial scales (e.g. Clough et al. 2005; Gallé et al. 2019). Croplands are subject to periodical withinfield disturbances, such as tillage, fertilization and pesticide applications, with long-term detrimental consequences on arthropods (e.g. Batáry et al. 2008; Sądej et al. 2012). In some cases, fields are left bare during winter (Kleijn et al. 2009). The availability of resources in croplands is therefore highly dynamic, resulting in strong spatiotemporal variation in habitat utilization (Kromp 1999; Rand et al. 2006). When crops are disturbed, arthropods, as well as other farmland animals, may depend on perennial non-crop habitats adjacent to arable fields (between-field scale). Various types of non-crop habitats (e.g. field boundaries, fallows, grasslands, woodlands and hedgerows) provide refuge, alternative prey sources, nesting and overwintering sites (e.g. Landis et al. 2000; Clough et al. 2005; Kovács-Hostyánszki et al. 2011; Kovács-Hostyánszki and Báldi 2012). During the growing season, these habitats may act as sources for arthropods for crop recolonization (Clough et al. 2005; Tscharntke et al. 2005; Bianchi et al. 2006; Schellhorn et al. 2014). Hence, the potential species pool filtered by landscape simplification might be further influenced at local scales by habitat type and crop management resulting in locally distinct arthropod assemblages (Duflot et al. 2014).

Based on the aforementioned studies, it is evident that agricultural intensification and environmental filtering significantly shape the structure of invertebrate assemblages in croplands. Overall, this resulted in a decrease in arthropod diversity (Hendrickx et al. 2007; Gámez-Virués et al. 2015). In order to counteract or, at least, mitigate the negative effect of environmental filtering, the European Community introduced specific agri-environmental schemes (AES, Batáry et al. 2015). In Hungary, set-aside fields were introduced as part of the national AES program in 2002 following accession to the European Community (Ángyán et al. 2003). Set-aside fields were designed specifically for the protection of the great bustard (Otis tarda) and other protected farmland bird species, but their establishment has also been beneficial for non-target groups of animals and plants (Kovács-Hostyánszki et al. 2011; Kovács-Hostyánszki and Báldi 2012; Tóth et al. 2018). In consequence, AES can also act to enhance ecosystem services, such as pest control or pollination. This ecological intensification (Bommarco et al. 2013) can sustain agricultural production with the least possible adverse effects on the environment by complementing or replacing artificial inputs with ecosystem services to increase crop productivity (Kleijn et al. 2019).
Nevertheless, the effectiveness of specific AES habitats at alleviating environmental filtering and delivering benefiting ecosystem services is still poorly understood because the environmental impact assessment of AES focuses on broad measures (Batáry et al. 2015). Moreover, it is also relatively unknown how arthropod assemblages and especially their functional traits are filtered at multiple spatial scales because studies addressing functional-trait based approaches are still rare (Gámez-Virués et al. 2015, but see Aviron et al. 2005 and Gallé et al. 2019).

These knowledge gaps prompted us to examine the assemblage structure of natural enemies using a hierarchical approach, from local to landscape scales. As model groups, we selected ground beetles (Coleoptera: Carabidae, hereafter carabids) and spiders (Araneae) because of their significant contribution to the biodiversity (including functional diversity) in agroecosystems (Greenstone 1999; Kromp 1999). Although carabids and spiders are important ecosystem service providers (Bommarco et al. 2013; Gagic et al. 2017; Martin et al. 2019), the effect of environmental filtering on them can vary depending on their functional traits. Utilizing a functional-trait based approach may provide better insight into the various processes in dynamic of agricultural landscapes than only considering taxonomic differences, such as species richness and/or abundance (Knapp et al. 2019; Magura and Lövei 2019; Martin et al. 2019). Whereas some functional traits, such as body size, wing morphology (as a proxy for dispersal) and habitat affinity (a proxy for fidelity) reflect environmental filtering through dispersal and their connection with feeding is indirect, hunting strategy is directly linked with the potential impact on pest populations (Schmidt-Entling and Döbeli 2009; Duflot et al. 2014; Anjum-Zubair et al. 2015; Gámez-Virués et al. 2015; Gallé et al. 2018, 2019; Martin et al. 2019).

In this study, we investigated how the local management in the form of inorganic fertilization and soil properties (within-field scale), habitat type including the newlyestablished AES habitat (between-field scale) and landscape complexity (landscape scale) affected carabid and spider assemblages in Hungary. In particular, we focused on their species richness, abundance and functional diversity. In the latter case, species were categorized according to their functional traits (body size, habitat affinity, wing morphology or hunting strategy), and these groups were analyzed separately to distinguish between the effects attributable to a specific group. We aimed to test the following hypotheses:

(i) The abundance, species richness and functional diversity of both carabids and spiders would be higher in croplands with improved soil fertility (i.e. neutral $\mathrm{pH}$, high amount of soil organic matter, hereafter SOM) and without inorganic fertilization. Contrarily, these assemblage patterns would be lower in 
croplands, where intensive use of fertilizer attempted to compensate the SOM deficit.

(ii) Newly-established set-aside fields, as the most common AES habitat adopted in the study region, adjacent to croplands provide a more suitable environment for carabids and spiders and would act as source habitats for recolonization in arable crops. Thus we expect that presence of set-asides improves either the taxonomic or the functional diversity of these pest control providers.

(iii) The high amount of semi-natural habitats (e.g. forests, hedgerows and grasslands) around arable lands leads to higher complexity at the landscape scale. This improved spatial heterogeneity in landscape composition is expected to support high taxonomic and functional diversity of carabids and spiders through improved dispersal and colonization conditions compared to simple landscapes.

\section{Materials and methods}

\section{Experimental area}

Our study was conducted in the lowland of Heves region in north-eastern Hungary. The area is characterized by arable fields (dominated by winter wheat, spring and winter barley, and maize) and areas under the AES program. In general, the number of available sites within the study region was restricted. We selected seven winter wheat fields with a size of 5-10 ha (for GPS coordinates, see ESM-Table 1). Each winter wheat field had an adjacent, newly-established (1-3 years old) set-aside field pair (size 1.98-5.43 ha). Set-aside fields are the most common AES habitats adopted in Heves region (Kovács-Hostyánszki and Báldi 2012). Originally, these set-aside fields used to be arable fields and have been taken out of production for a 5-year contract period. At the beginning of this contract period, they were sown by a legume-grass seed mixture composed of Medicago sativa, grasses of Lolium sp. and Festuca sp. to ensure an organic matter enrichment (Ángyán et al. 2003). Apart from legumes and grass, several wild plants germinated from the seed bank. The vegetation cover was similar for all set-aside fields; they were mown once in a year in the second half of June, leaving the hay on the ground. No insecticides or herbicides were used during the contract period.

In each of seven winter wheat fields, we assigned a plot of $45 \times 20 \mathrm{~m}$ in the central section adjacent to a set-aside field to avoid any edge effects from other areas. Farmers were not allowed to use insecticides within this experimental plot, while normal conventional management was applied to the rest of the field. Each experimental plot was divided into two subplots of $20 \times 20 \mathrm{~m}$ with a $5 \mathrm{~m}$ separation strip to avoid any interference between treatments (Fig. 1). One subplot was treated with NPK fertilizer at the usual rate of $95 \mathrm{~kg} \mathrm{~N} /$ ha in mid-April 2014, while the other half, without fertilizer input, served as control. Since fertilization treatment was not applied to the set-aside field, our sampling design was not fully factorial between habitats and fertilizer use. The distance between study site pairs (i.e. pairs of winter wheat field and adjacent set-aside field) was between 1.21 and $10.08 \mathrm{~km}$ (mean: $4.09 \mathrm{~km}$ ).

In each winter wheat subplot, 15 soil samples were taken randomly when the wheat plants reached the stem elongation stage $10+$ at the BBCH scale (Zadoks et al. 1974). Soil samples were stored at $4{ }^{\circ} \mathrm{C}$ until SOM and pH were measured. Prior to analyses, samples from each experimental field were sieved (4 $\mathrm{mm}$ mesh size), blended and then combined for analyses. Soil analyses were conducted according to Hungarian standards (no. 08-0452 and 08-0206-2) and the literature (Mason 1983). SOM content varied from 2.45 to $4.09 \%$, and the $\mathrm{pH}$ range was 4.74-6.59.

In $1 \mathrm{~km}$ radius around the experimental winter wheat fields, we estimated the complexity of landscape using a GIS database implemented by local authorities. Landscapes with $>20 \%$ of semi-natural habitats (semi-natural grasslands, forests, hedgerows and other non-crop elements) within this radius were classified as complex, while those with $<20 \%$ of such habitats were classified as simple (Batáry et al. 2008, 2011; Tscharntke et al. 2011). In addition, the average distance between fields was greater than $2 \mathrm{~km}$, thus exceptional partial overlap of landscapes did not bias the spatial independence. Four of the seven landscape windows around the seven winter wheat fields were complex, and three were simple (see ESM-Table 1).

\section{Arthropod sampling and functional traits}

In each winter wheat subplot, we installed four pitfall traps to sample carabids and spiders at 10 and $20 \mathrm{~m}$ (two traps $10 \mathrm{~m}$ apart in each distance, Fig. 1) from the inner edge of the wheat fields adjacent to the set-aside field. Four pitfall traps were also placed in set-aside fields using the same sampling arrangement. In total, we installed 84 traps: 28 in fertilized winter wheat (four traps per subplot, seven subplots in total), 28 in control winter wheat and 28 in set-aside fields. Pitfall traps were plastic cups of $114 \mathrm{~mm}$ diameter filled with approximately $250 \mathrm{ml}$ of 50\% propylene glycol solution saturated with $\mathrm{NaCl}$ and a drop of odorless detergent to reduce surface tension. Green plastic roofs were installed to protect traps from litter and rain. All traps were open for 10 days at the beginning of June 2014 (between 3rd and 13th June). The collected material was sorted in the laboratory and spiders and carabids were identified to species level using keys in Loksa (1969, 1972), Heimer and Nentwig (1991), Nentwig et al. (2019), 


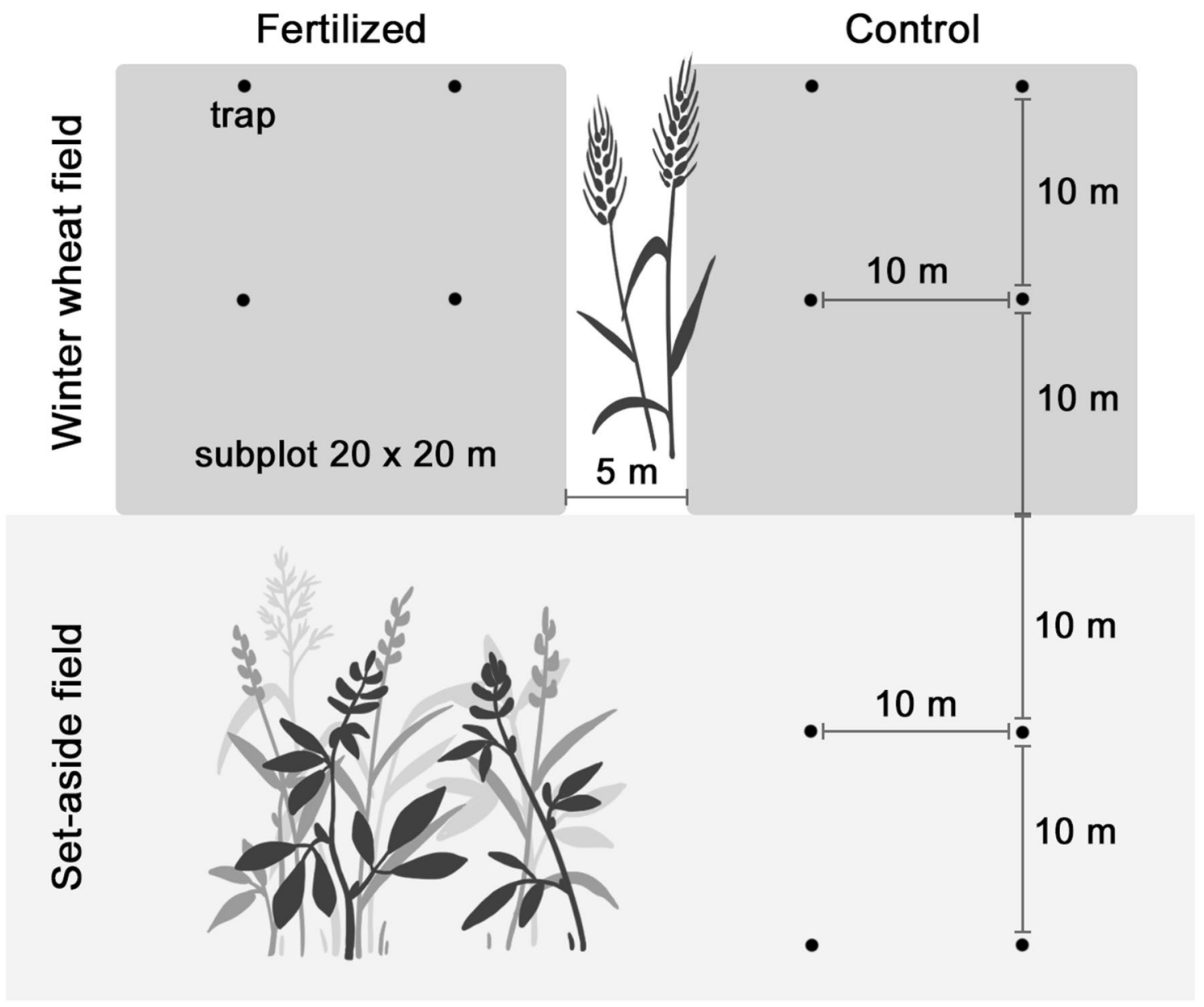

Fig. 1 Spatial arrangement of pitfall traps in winter wheat subplots and set-aside fields

and Hůrka (1996), respectively. Even though our sampling season was rather short, it coincided with the flowering and milky ripening stages of winter wheat one month before harvest, and with the late spring activity peaks of ground-dwelling arthropods (Anjum-Zubair et al. 2015; Madeira et al. 2016; Gagic et al. 2017), making it suitable for our comparative purposes.

Activity density (counts from pitfall traps are more properly described as activity density than abundance) and species richness of both predatory groups per trap were calculated. For each carabid species, we recorded the following functional traits: body size (small: $<10 \mathrm{~mm}$, medium: $10.1-15 \mathrm{~mm}$ or large: $>15.1 \mathrm{~mm}$ ), flight ability (macropterous or brachypterous) and habitat affinity (generalist, open or forest habitat specialist) according to Hůrka (1996). For spiders, body size (small: $<5 \mathrm{~mm}$, medium: $5.1-10 \mathrm{~mm}$ or large: $>10.1 \mathrm{~mm}$ ), hunting strategy (running spiders, stalkers, and sheet- or aerial-web builders) and habitat affinity (generalist, open or forest habitat specialist) was obtained from Uetz et al. (1999), Buchar and Růžička (2002) and Nentwig et al. (2019).

\section{Statistical analyses}

The expected species richness of carabids and spiders was estimated in set-aside fields and winter wheat fields with the Chao estimator (Chao 1987) using the specaccum function in the 'vegan' package (Oksanen et al. 2017). The standard deviations were generated from 10,000 reshufflings of the sample order. The diversity of carabid and spider assemblages at the within-field (fertilization treatment), the between-field (habitat type), and landscape scale (landscape complexity) was compared by the Rényi one-parametric diversity index family. This approach does not consider only one numerical value (Tóthmérész 1995), but calculates an assemblage diversity profile by plotting several diversities against a scale parameter (Lövei 2005; Ricotta 2005; Elek and Tóthmérész 2010). When the scale parameter, $\alpha=0$, the value of the Rényi diversity equals the logarithm of species richness. At this stage, the index is very sensitive to the presence of rare species. When $\alpha \approx 1$, the Rényi diversity corresponds to the Shannon diversity. As the scale parameter increases, the Rényi 
diversity becomes more sensitive to the relative abundance of the more common species. At $\alpha=2$, the plotted value equals the quadratic (Simpson) diversity. Towards $\alpha \approx$ $+\infty$, values approach the inverse of the Berger-Parker dominance index, which is determined by the abundance of the most common species only. If the Rényi diversity profiles of two assemblages intersect, the assemblages can still be compared, but the comparison should be given for different section of profiles in relation to rarity and dominance of the species set (Lövei 2005). For the calculation of the Rényi diversity, we used the renyi function from the 'vegan' package (Oksanen et al. 2017).

We applied separate analyses for activity density and species richness of carabids and spiders and selected functional traits of both groups. For functional trait analyses, a subset was created for each category in a given functional trait. For instance, the trait of body size of carabids was included as a factor with three trait levels: small, medium-sized and large carabids. However, only categories with at least 200 individuals were used for further analyses to achieve robustness of the data; thus, small, medium-sized, macropterous and open-habitat carabids and small, medium-sized, running, stalking, open-habitat and generalist spiders were included in the analyses. First, we tested the predictive power of all studied explanatory variables and possible correlations using the random forest algorithm from the 'party' package (Strobl et al. 2008). Then, we used linear mixed-effect models, where species richness of carabids and spiders and activity density of running spiders and the whole assemblage were squareroot transformed; while the rest of response variables were $\log$ transformed to normalize data distribution. We used the lme function from the 'nlme' package (Pinheiro et al. 2017) and included treatment (two levels: control or fertilizer), habitat type (two levels: winter wheat field or set-aside field), $\mathrm{pH}$ (continuous), SOM (continuous) and landscape complexity (two levels: simple or complex) as explanatory variables and study site ID (seven levels) as a random effect. For each carabid and spider data subset (i.e. activity density, species richness and category in a given functional trait), we fitted a maximal model that included all explanatory variables and meaningful interactions. Following this, non-significant interactions and variables were gradually removed (model simplification) to reach the most parsimonious model. ANOVA with a $\chi^{2}$ test was used to test the significance of explanatory variables (the Anova function from the 'car' package, Fox and Weisberg 2010). To select the most parsimonious model within each subset, we calculated the weight of each model based on the AICc using the model.sel function of the 'MuMIn' package (Bartoń 2016). Model selection showed that the most parsimonious model was also the best one in all analyzed subsets. All analyses given above were conducted in R 3.4.1 (R Core Team 2017).

\section{Results}

\section{Assemblage characteristics for both predatory arthropod groups}

In total, we collected 3878 carabids of 39 species (ESMTables 2 and 3). The assemblage was characterized by the dominance of small (24 species; 3399 individuals), macropterous $(36 ; 3801)$ and open habitat-preferring $(34 ; 3770)$ carabids. Three Brachinus species were the most abundant ones, particularly B. crepitans (L., 1758) (1028 individuals, 26.5\% of all trapped carabids), B. ganglbaueri Apfelbeck, 1904 (755 individuals, 19.4\%), and B. explodens Duftschmid, 1812 (600 individuals, 15.5\%). For spiders, 2109 individuals of 66 species were collected (ESM-Tables 2 and 4) with small (38 species; 1295 individuals), running (40; 1658), and open-habitat $(44 ; 1553)$ spiders as dominant groups in the assemblage. Pardosa agrestis (Westring, 1861) was the most abundant species (922 individuals, $43.65 \%$ of all spiders captured).

\section{Estimated species richness and assemblage diversity}

The species richness estimation revealed that it did not change substantially after the 20th carabid sample in setaside fields (27.25 species \pm 0.7 SD, ESM-Fig. 1a), but no saturation was evident for carabids in winter wheat fields (ESM-Fig. 1b) and for spiders in both habitat types (ESMFig. 1c, ESM-Fig. 1d). The Rényi diversity profiles at the within-field scale revealed a negative effect of fertilizer use on carabids (Fig. 2a), but for spiders, this effect was not strong (Fig. 2b). At the between-field scale, the diversities of both groups were similar, with the diversity profiles intersecting: for rare species, the diversity was higher in the winter wheat fields than in the set-aside ones. Considering the more abundant species of both carabids and spiders, their diversity was higher in set-aside fields than in winter wheat (Fig. 2c and d). At the landscape scale, carabid diversity was at the same level for rare species in both landscape types, however for the most abundant species, it was higher in simple landscapes (Fig. 2e). Spider diversity was slightly higher in the complex landscapes than the simple ones (Fig. 2f).

\section{Responses to within-field, between-field and landscape factors}

At the within-field scale, soil $\mathrm{pH}$ had a positive (Fig. 3a and b) while the SOM a slight negative effect (Fig. 3c and d) 

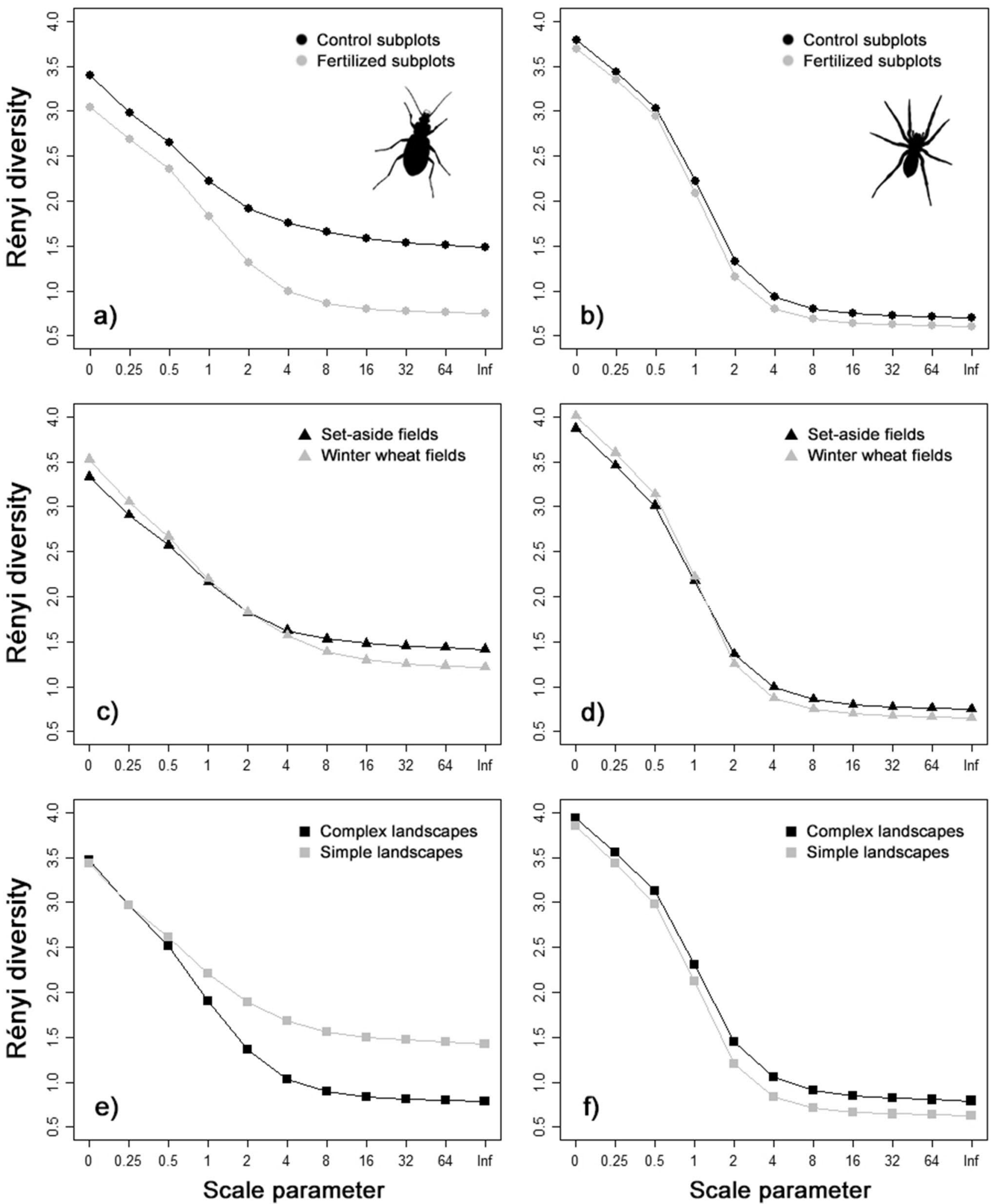

Fig. 2 Diversity profiles of carabid $(\mathbf{a}, \mathbf{c}, \mathbf{e})$ and spider assemblages $(\mathbf{b}, \mathbf{d}, \mathbf{f})$ in different winter wheat subplots, habitats and landscapes by Rényi diversity 

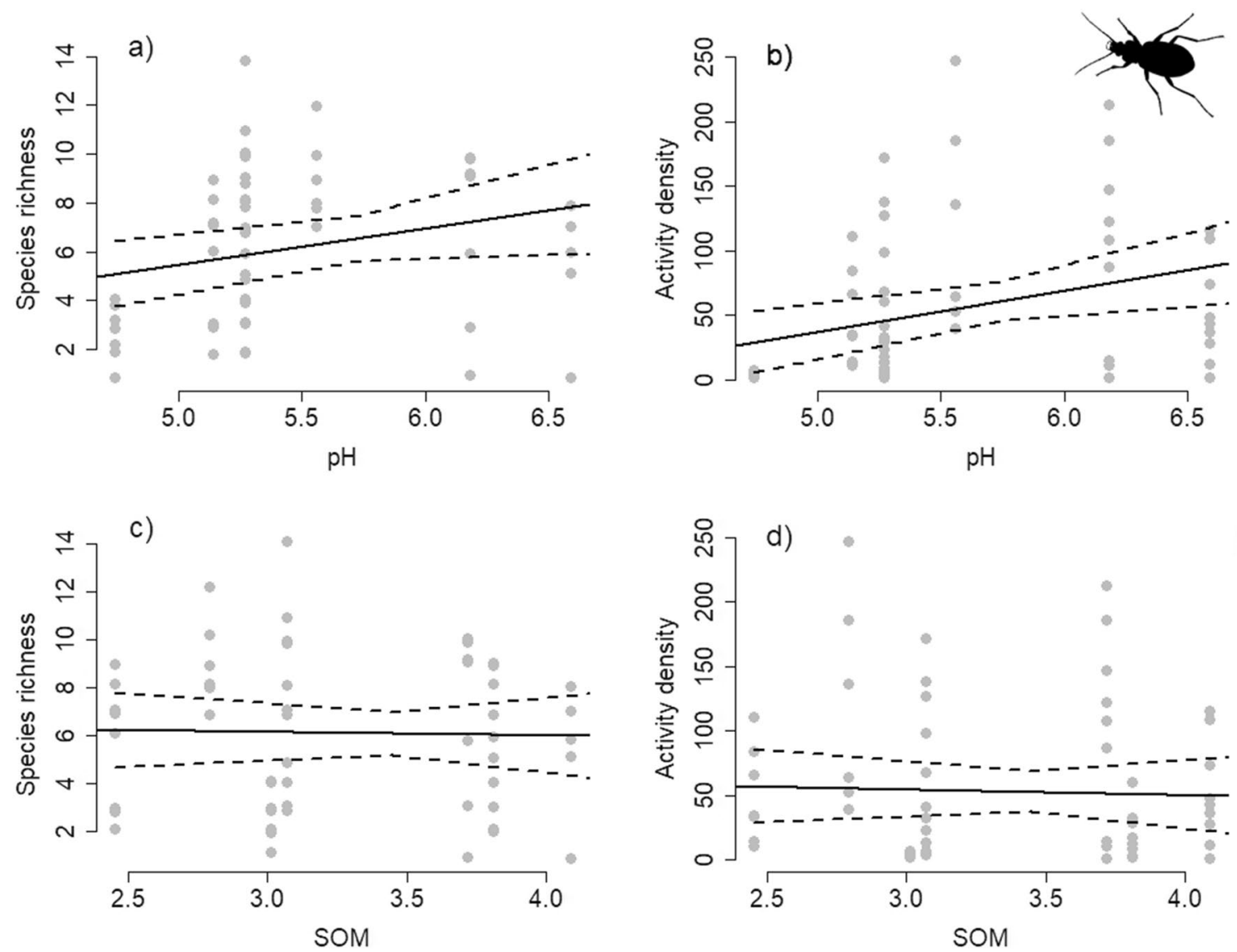

Fig. 3 Response of species richness (a, c) and activity density (b, d) of carabids to soil properties. Dashed lines represent $95 \%$ confidence interval

on species richness and activity density of all carabids, as well as on small, macropterous and open habitat species. Although the inorganic fertilizer reduced species richness of carabids by $35.3 \%$ (Fig. 4a), their activity density remained unaffected (Table 1). At between-field scale, the activity density of all carabids, and that of small, macropterous and open-habitat species was significantly higher in set-aside fields than in winter wheat fields, regardless of fertilization. The activity density of the assemblage was $49.5 \%$ lower in winter wheat than in set-asides fields (Fig. 4b). At the landscape scale, carabid species richness was $18.7 \%$ lower in complex landscapes than in the simple ones, while their activity density was reduced by $27.8 \%$ (Fig. $4 c$ and d). Similarly, small, medium-sized and open habitat species were significantly more abundant in simple landscapes than in the complex ones (Table 1).

Spider species richness as well as activity density was significantly affected only at the between-field scale (Table 1). Species richness was $25.1 \%$ lower and activity density was reduced by $44.1 \%$ in winter wheat fields than in adjacent setaside fields (Fig. 5a and b). Small-sized species and stalkers also had low activity densities in winter wheat fields
(Table 1). Medium-sized, running and generalist spiders did not significantly respond to any variables. Fertilizer treatment, soil properties or landscape complexity had no impact on the examined characteristics of spider assemblages.

\section{Discussion}

In this cultivated landscape, assemblages of both carabids and spiders were characterized by highly mobile, small, open-habitat-preferring species which can indicate a highly dynamic environment. The dominance of few but very abundant agrobiont species in both groups suggested the influence of strong environmental filters acting at different spatial scales. While spiders did not respond at the landscape scale, simple landscapes supported more abundant but functionally less diverse carabid assemblages. Highly mobile (macropterous) carabids can colonize arable crops from greater distances, while ground-dwelling spiders depend on the proximity of set-aside fields. Overall, winter wheat fields (where pest control should be delivered) were utilized mostly by 

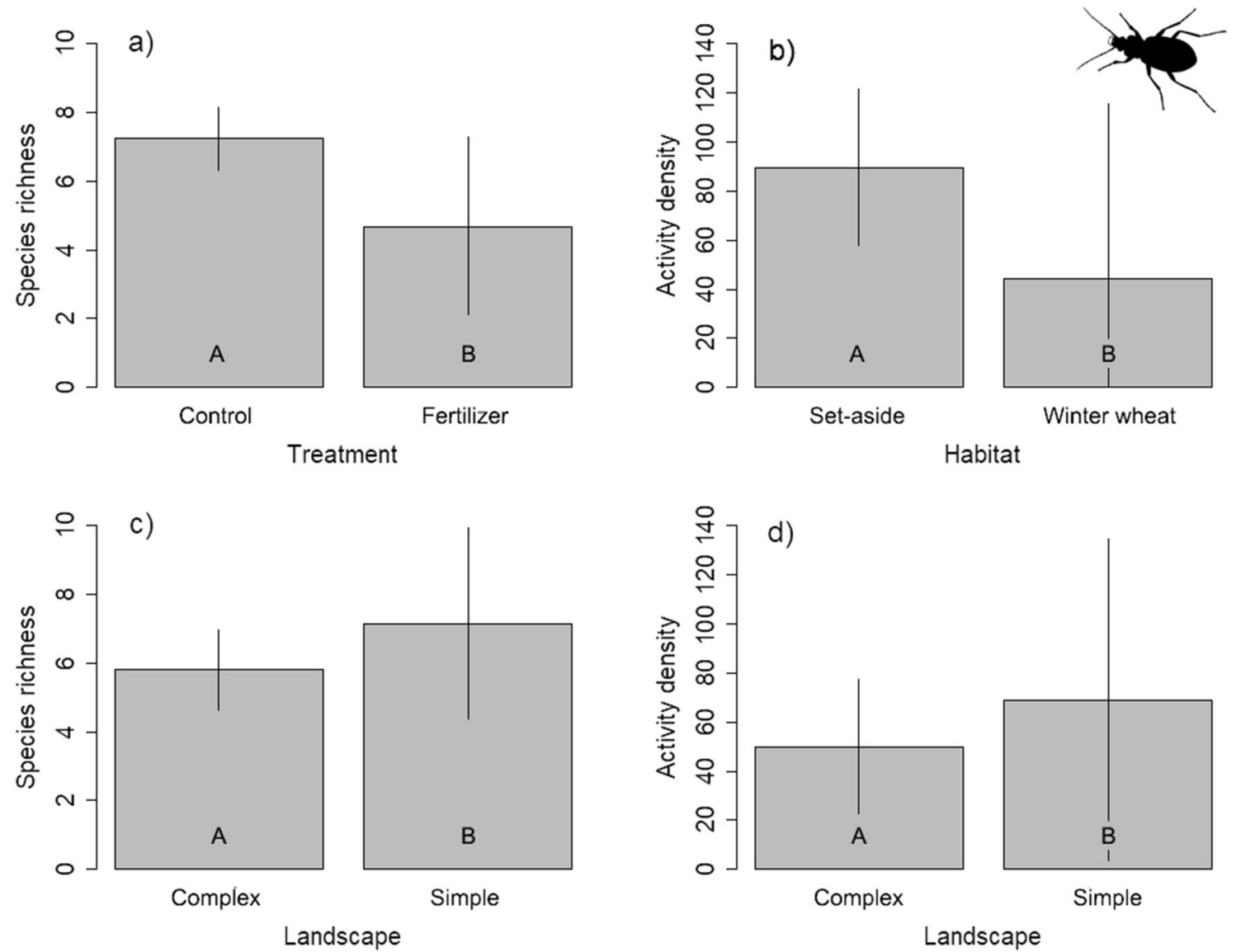

Fig. 4 Response of species richness (a, $\mathbf{c})$ and activity density $(\mathbf{b}, \mathbf{d})$ of carabids to fertilization treatment, habitat type and landscape composition. Whiskers represent $95 \%$ confidence interval and capital letters at the bottom of bars indicate significant differences

common agrobiont species that could be additionally influenced by fertilization.

\section{Within-field scale}

Only carabids were affected at the within-field scale. Here, the species richness of carabids was negatively affected by inorganic fertilization, conforming to the prediction by our first hypothesis (i). The impact of fertilizer use on carabids is primarily indirect, acting through soil- and crop-related features, such as vegetation (crop) structure, diversity of weeds, and overall plant productivity (Siemann 1998; Kromp 1999). This can lead to changes in the availability of below- and above-ground food resources for carabids and consequently affects their spatial distribution (Hole et al. 2005; Pakeman and Stockan 2014; Mader et al. 2018). Individual carabid species such as Amara aenea (De Geer, 1774) and Chlaenius festivus (Panzer, 1796) might react to these microhabitat changes by avoiding fertilized patches, whilst other species showed slight preferences for either the fertilized or the control subplot (ESM-Table 3). In addition, lower species richness and diversity in the fertilized subplots suggest the existence of environmental filtering and a potential decrease in biological pest control within arable fields (Tscharntke et al. 2016). Our findings are similar to those of Sacdej et al. (2012), who observed fewer carabid species in plots fertilized by inorganic nitrogen but non-significant drop in activity density. Also, Honczarenko (1975) reported that some carabid species totally avoided plots with high doses of inorganic fertilizer and were concentrated in non-fertilized control plots.

In general, higher $\mathrm{pH}$ had a positive, while $\mathrm{SOM}$ a negative effect on carabids, providing partial support for our first hypothesis (i). Soils with neutral $\mathrm{pH}$ are characterized by a higher diversity of various ground-dwelling organisms including carabids (Kuperman 1996; Scheu 2001; Sądej et al. 2008; Tamburini et al. 2016). Although the fauna living in soils with a high content of SOM can serve as a good food source for ground-dwelling predators, thus resulting in higher numbers of carabids (Pfiffiner and Luka 2000; Sądej et al. 2012), we found the opposite pattern. It is likely that this is due to shifts in carabid assemblage 
Table 1 The response of carabids and spiders to fertilization treatment, soil properties (within-field scale), habitat type (between-field scale) and landscape complexity (landscape scale) based on bestfitted models according to AICc

\begin{tabular}{|c|c|c|c|c|c|c|}
\hline Response variables & $\begin{array}{l}\text { No. of } \\
\text { individu- } \\
\text { als }\end{array}$ & Explanatory variables & $\chi^{2}$ & df & $\mathrm{p}$ & Comparisons \\
\hline \multicolumn{7}{|l|}{ Ground beetles } \\
\hline \multirow[t]{4}{*}{ Species richness } & \multirow[t]{4}{*}{3878} & Treatment & 7.827 & 1 & 0.005 & Control $>$ fertilizer \\
\hline & & SOM & 5.137 & 1 & 0.023 & $\downarrow$ \\
\hline & & $\mathrm{pH}$ & 11.114 & 1 & $<0.001$ & $\uparrow$ \\
\hline & & Landscape & 4.609 & 1 & 0.031 & Simple $>$ complex \\
\hline \multicolumn{7}{|l|}{ Activity density } \\
\hline \multirow[t]{4}{*}{ All individuals } & \multirow[t]{4}{*}{3878} & Habitat & 3.886 & 1 & 0.048 & Set-aside $>$ wheat \\
\hline & & SOM & 19.795 & 1 & $<0.001$ & $\downarrow$ \\
\hline & & $\mathrm{pH}$ & 31.715 & 1 & $<0.001$ & $\uparrow$ \\
\hline & & Landscape & 6.793 & 1 & 0.009 & Simple $>$ complex \\
\hline \multirow[t]{4}{*}{ Small beetles } & \multirow[t]{4}{*}{3399} & Habitat & 6.915 & 1 & 0.009 & Set-aside $>$ wheat \\
\hline & & SOM & 15.588 & 1 & $<0.001$ & $\downarrow$ \\
\hline & & $\mathrm{pH}$ & 31.217 & 1 & $<0.001$ & $\uparrow$ \\
\hline & & Landscape & 4.122 & 1 & 0.042 & Simple $>$ complex \\
\hline Medium-sized beetles & 340 & Treatment & 1.937 & 1 & 0.164 & \\
\hline \multirow[t]{4}{*}{ Macropterous beetles } & \multirow[t]{4}{*}{3801} & Habitat & 4.332 & 1 & 0.037 & Set-aside $>$ wheat \\
\hline & & SOM & 20.800 & 1 & $<0.001$ & $\downarrow$ \\
\hline & & $\mathrm{pH}$ & 32.461 & 1 & $<0.001$ & $\uparrow$ \\
\hline & & Landscape & 6.333 & 1 & 0.011 & Simple $>$ complex \\
\hline \multirow[t]{4}{*}{ Open habitat species } & \multirow[t]{4}{*}{3770} & Habitat & 3.967 & 1 & 0.046 & Set-aside $>$ wheat \\
\hline & & SOM & 19.724 & 1 & $<0.001$ & $\downarrow$ \\
\hline & & $\mathrm{pH}$ & 32.639 & 1 & $<0.001$ & $\uparrow$ \\
\hline & & Landscape & 5.551 & 1 & 0.018 & Simple $>$ complex \\
\hline \multicolumn{7}{|l|}{ Spiders } \\
\hline Species richness & 2109 & Habitat & 6.293 & 1 & 0.012 & Set-aside $>$ wheat \\
\hline \multicolumn{7}{|l|}{ Activity density } \\
\hline All individuals & 2109 & Habitat & 7.393 & 1 & 0.007 & Set-aside $>$ wheat \\
\hline Small spiders & 1295 & Habitat & 4.710 & 1 & 0.029 & Set-aside $>$ wheat \\
\hline Medium-sized spiders & 406 & $\mathrm{pH}$ & 3.388 & 1 & 0.066 & \\
\hline Runners & 1658 & Habitat & 3.618 & 1 & 0.057 & \\
\hline Stalkers & 282 & Habitat & 5.325 & 1 & 0.021 & Set-aside $>$ wheat \\
\hline Open habitat species & 1553 & Habitat & 3.030 & 1 & 0.081 & \\
\hline Generalist species & 298 & Habitat & 1.644 & 1 & 0.199 & \\
\hline
\end{tabular}

Numbers of individuals included in particular analyses are shown. Significant effects are in bold, marginal significant effects are in italic, and directions of significant relationships are designated by up and down arrows for continuous, or relations marks for factorial variables respectively composition mediated by open habitat species. Decreasing $\mathrm{pH}$ and increasing SOM content in mucky, peat-muck and peat soils negatively affect the activity density of mesophilous carabid species that were less tolerant to changing moisture conditions (Nietupski et al. 2010). In humus-rich soils, those mesophilous species are replaced by hygrophilous ones that were more associated with open habitats. We presume that the predominance of open habitat species in this study drove the overall response of the carabid assemblages via their negative response to increasing SOM content.

\section{Between-field scale}

At the between-field scale, in accordance with our second hypothesis (ii), we found that newly-established set-aside fields locally increased the activity density of carabids with the exception of medium-sized species (see below). The majority of carabid species used both habitats, but had lower activity densities in winter wheat than in set-aside fields. This might suggest that the spring colonization of winter wheat (at least partially) depended on adjacent set-aside fields. Set-aside fields, similarly to other non-crop habitats, 

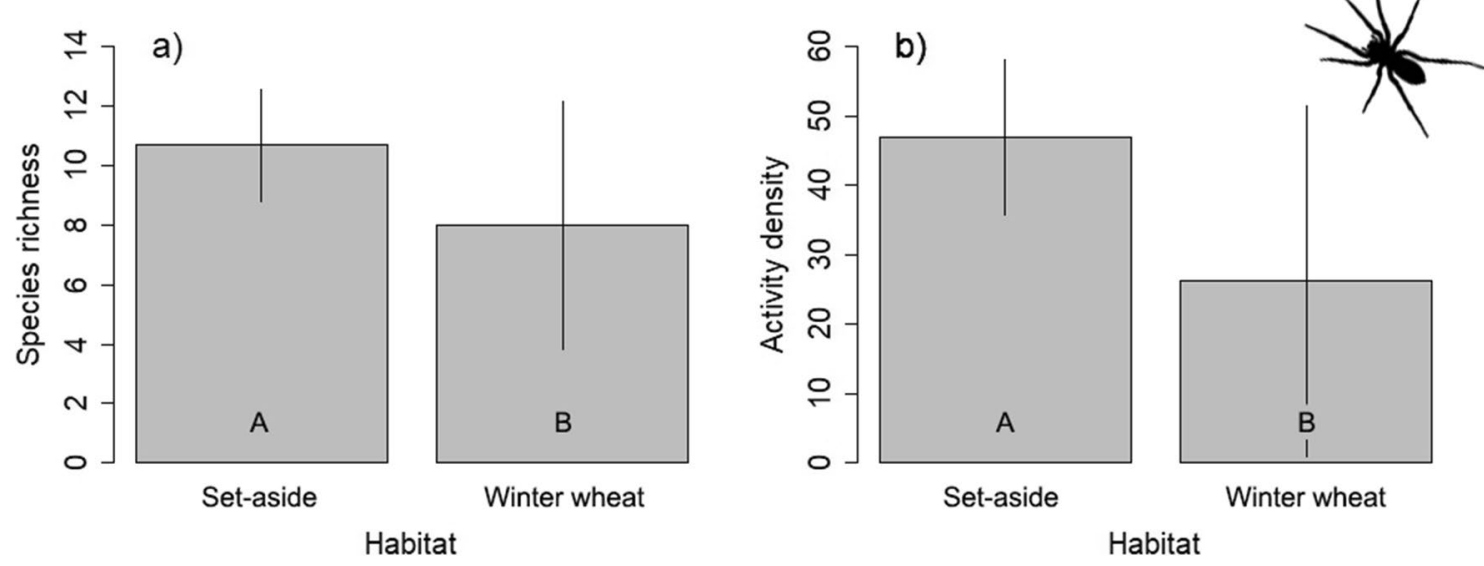

Fig. 5 Response of species richness (a) and activity density (b) of spiders to habitat type. Whiskers represent $95 \%$ confidence interval and capital letters at the bottom of bars indicate significant differences

may serve as refuges from where carabids can colonize crop fields (Pfiffner and Luka 2000; Fournier and Loreau 2001; Bianchi et al. 2006). Concerning medium-sized carabids, their activity density did not significantly change between habitats. This might be due to the predominance of Poecilus cupreus (L. 1758) (ESM-Table 3), a common species occurring primarily in arable fields (Mader et al. 2018). This agrobiont species can be found at boundaries with set-aside fields and other non-crop habitats, as well as in centers of arable fields, in high abundances, suggesting insensitivity to the filtering effect at between-field scale (Anjum-Zubair et al. 2015; Madeira and Pons 2016).

For spiders, only our second hypothesis (ii) was supported, because spiders were affected only at the betweenfield scale. It seems that a major driver for spider distribution in this study was the presence of set-aside fields, while inorganic fertilization, soil conditions in winter wheat fields, and landscape complexity were not important. Whereas some species of carabids can hibernate in arable fields and do not need adjacent non-crop habitats for completing their life cycles (Holland et al. 2007), in-crop-only persistence is very rare in spiders (Clough et al. 2005) and has been observed only in few species (Mestre et al. 2018). The spillover of spiders into arable crops therefore heavily depends on the proximity of adjacent set-aside fields and/or other types of non-crop habitats (Clough et al. 2005; Bianchi et al. 2006; Gallé et al. 2018). However, a significant drop in both species richness and activity density in winter wheat fields suggest the existence of an environmental filter between habitats because only some species, mostly belonging to running spiders, were found in winter wheat (ESM-Table 4); the other species stayed in the set-aside fields. Running spiders that moved into the wheat fields did so regardless of inorganic fertilization or SOM. Active hunters, such as P. agrestis, one of the most dominant running spiders in agroecosystems in Central Europe (Kiss and Samu 2000), can easily disperse from adjoining overwintering sites and colonize even large fields (Samu and Szinetár 2002). This can be also the reason why running and open habitat spiders did not react at the between-field scale. Spiders of other hunting strategies, such as stalkers, could be positively affected by the complex vegetation structure of set-aside fields resulting in higher abundances in this habitat type (Luff and Rushton 1989; Cole et al. 2005; Schellhorn et al. 2014). These results might be indirect evidence that the structured vegetation and high plant diversity in our set-aside fields (the vegetation cover was a legume-grass mixture with several wild plants from the seed bank) and extensive management without any chemical input favored stalking and ambush-hunting species, such as Ozyptila simplex (O. Pickard-Cambridge, 1862), by providing better hunting conditions via a higher availability of shelters than in winter wheat fields.

\section{Landscape scale}

At the landscape scale, contrary to the third hypothesis (iii), we found no effect of landscape complexity on spiders, while carabid assemblages were more species-rich and abundant in simple landscapes than in complex ones. Carabid assemblages in agroecosystems might be unsaturated due to the depletion of specialist species that have a moderate dispersal capacity (Aviron et al. 2005; Duflot et al. 2014). Structurally complex landscapes mitigate this depletion due to the presence of semi-natural and other non-crop habitats, supporting recolonization of temporarily suitable crop fields and counteracting biotic homogenization (Hendrickx et al. 2007; Fahrig et al. 2011; Gáméz-Virués et al. 2015). However, our results showed the opposite pattern. For small, open habitat-preferring species, complex landscapes might act as a barrier and reduce their dispersal due to unfavorable 
conditions in semi-natural habitats (Mauremooto et al. 1995; Al Hassan et al. 2013). In simple landscapes, a very high species-turnover of common agrobionts compensates this species depletion, leading to the species-rich and abundant but functionally less diverse assemblage (Aviron et al. 2005; Martin et al. 2019). In spiders, the lack of response at the landscape scale might be due to the distance considered in this study ( $1 \mathrm{~km}$ around winter wheat fields). It is possible that spider assemblages were affected at a higher or lower scale. In future studies, measuring the landscape heterogeneity at multiple distances $(500 \mathrm{~m}, 1 \mathrm{~km}, 3 \mathrm{~km}$ from the study area) could help to identify the scale of landscape effects on ground-dwelling arthropods in agroecosystems.

\section{Conclusions}

Carabids and spiders are important providers of ecosystem services to promote ecological intensification. Particular AES programs should be planned in a broader context including multiple spatial scales to sustain these services. Set-aside fields may support natural enemies locally but the existence of scale-dependent environmental filters may diminish their efficiency. Although our results did not provide direct evidence, we suggest that dispersal ability and sensitivity to fertilization play a crucial role in trait-specific responses of carabids and spiders. It is also important to consider the cost/benefit ratio of the proposed AES habitat. Establishing and maintaining set-aside fields is relatively costly and not very popular among farmers due to reduction of the area under production and consequent lower yield (see Kleijn et al. 2019). Since winter wheat fields were utilized mostly by common agrobiont carabids and spiders as a result of scale-dependent environmental filters, management adjustments should be focused on arable fields rather than their boundaries. Increasing crop diversity and vegetation heterogeneity may support the taxonomic and functional diversity of carabids and spiders in crops where pest control should be achieved. Growing multiple crops simultaneously in the same field with reduced fertilizer use could be a potential option for farmers that want to support natural pest control (Kleijn et al. 2019). Nevertheless, these suggestions may only be appropriate for this study region. In addition, short-term sampling scheme provides only a snapshot in the complex dynamics of ground-dwelling arthropods in agroecosystems and thus the generalization of our results might be limited. The effect of environmental filtering on natural enemies may vary in relation to different parts of the season, crop type, AES habitat and/or region of Europe. Various AESs can be effective tools for ecosystem intensification but they have to be carefully designed and targeted (Batáry et al. 2015).
Acknowledgements Open access funding provided by Eötvös Loránd University. We thank all the farmers who allowed us to work on their fields, László Tóth at Bükk National Park Directorate for his help in the selection of the field sites, as well as during the study, Dorottya Molnár and Gergely Boros for field assistance, and Gábor L. Lövei for linguistic corrections. This study was funded by the EU FP7-project LIBERATION (LInking farmland Biodiversity to Ecosystem seRvices for effective ecological intensificATION; Project Number 311781), by the National Research Development and Innovation Office (GINOP2.3.2-15-2016-00019), JR was supported by an Erasmus + traineeship, AKH was a Bolyai Fellow.

\section{Compliance with ethical standards}

Conflict of interest The authors declare that they have no conflict of interest.

Ethical approval The field sampling of carabids and spiders was conducted under the license from the respective Hungarian authority (Közép-Duna-Völgyi Környezetvédelmi és Természetvédelmi Felügyelőség KTF:30362-3/2014).

Open Access This article is licensed under a Creative Commons Attribution 4.0 International License, which permits use, sharing, adaptation, distribution and reproduction in any medium or format, as long as you give appropriate credit to the original author(s) and the source, provide a link to the Creative Commons licence, and indicate if changes were made. The images or other third party material in this article are included in the article's Creative Commons licence, unless indicated otherwise in a credit line to the material. If material is not included in the article's Creative Commons licence and your intended use is not permitted by statutory regulation or exceeds the permitted use, you will need to obtain permission directly from the copyright holder. To view a copy of this licence, visit http://creativecommons.org/licenses/by/4.0/.

\section{References}

Al Hassan D, Georgelin E, Delattre T, Burel F, Plantegenest M, Kindlmann P et al (2013) Does the presence of grassy strips and landscape grain affect the spatial distribution of aphids and their carabid predators? Agric Forest Entomol 15:24-33. https ://doi.org/10.1111/j.1461-9563.2012.00587.x

Anjum-Zubair M, Entling MH, Bruckner A, Drapela T, Frank T (2015) Differentiation of spring carabid beetle assemblages between semi-natural habitats and adjoining winter wheat. Agric Forest Entomol 17:355-365. https://doi.org/10.1111/ afe. 12115

Aviron S, Burel F, Baudry J, Schermann N (2005) Carabid assemblages in agricultural landscapes: impacts of habitat features, landscape context at different spatial scales and farming intensity. Agric Ecosyst Environ 108:205-217. https://doi. org/10.1016/j.agee.2005.02.004

Bartoń K (2016) MuMIn: multi-Model Inference. https://CRAN.Rproject.org/package=MuMIn. Accessed 15 Sept 2017

Batáry P, Kovács A, Báldi A (2008) Management effects on carabid beetles and spiders in Central Hungarian grasslands and cereal fields. Community Ecol 9:247-254. https://doi.org/10.1556/ ComEc.9.2008.2.14

Batáry P, Báldi A, Kleijn D, Tscharntke T (2011) Landscape-moderated biodiversity effects of agri-environmental management: 
a meta-analysis. Proc R Soc B 278:1894-1902. https://doi. org/10.1098/rspb.2010.1923

Batáry P, Dicks LV, Kleijn D, Sutherland WJ (2015) The role of agrienvironment schemes in conservation and environmental management. Conserv Biol 29:1006-1016. https://doi.org/10.1111/ cobi.12536

Bianchi FJ, Booij CJH, Tscharntke T (2006) Sustainable pest regulation in agricultural landscapes: a review on landscape composition, biodiversity and natural pest control. Proc R Soc B 273:1715-1727. https://doi.org/10.1098/rspb.2006.3530

Bommarco R, Kleijn D, Potts SG (2013) Ecological intensification: harnessing ecosystem services for food security. Trends Ecol Evol 28:230-238. https://doi.org/10.1016/j.tree.2012.10.012

Buchar J, Růžička V (2002) Catalogue of spiders of the Czech Republic. Peres Publishers, Praha

Cadotte MW, Tucker CM (2017) Should environmental filtering be abandoned? Trends Ecol Evol 32:429-437. https://doi. org/10.1016/j.tree.2017.03.004

Chao A (1987) Estimating the population size for capture-recapture data with unequal catchability. Biometrics 43:783-791. https:// doi.org/10.2307/2531532

Clavel J, Julliard R, Devictor V (2011) Worldwide decline of specialist species: toward a global functional homogenization? Front Ecol Environ 9:222-228. https://doi.org/10.1890/080216

Clough Y, Kruess A, Kleijn D, Tscharntke T (2005) Spider diversity in cereal fields: comparing factors at local, landscape and regional scales. J Biogeogr 32:2007-2014. https://doi.org/10.1 111/j.1365-2699.2005.01367.x

Cole LJ, McCracken DI, Downie IS, Dennis P, Foster GN, Waterhouse $\mathrm{T}$ et al (2005) Comparing the effects of farming practices on ground beetle (Coleoptera: Carabidae) and spider (Araneae) assemblages of Scottish farmland. Biodivers Conserv 14:441460. https://doi.org/10.1007/s10531-004-6404-z

Duflot R, Georges R, Ernoult A, Aviron S, Burel F (2014) Landscape heterogeneity as an ecological filter of species traits. Acta Oecol 56:19-26. https://doi.org/10.1016/j.actao.2014.01.004

Elek Z, Tóthmérész B (2010) Carabid beetles among grassland forest edge - beech forest habitats in Northern Hungary. Community Ecol 11:211-216. https://doi.org/10.1556/ComEc .11 .2010 .2 .9

Ewers RM, Didham RK (2006) Confounding factors in the detection of species responses to habitat fragmentation. Biol Rev 81:117-142. https://doi.org/10.1017/S1464793105006949

Fahrig L, Baudry J, Brotons L, Burel FG, Crist TO, Fuller RJ et al (2011) Functional landscape heterogeneity and animal biodiversity in agricultural landscapes. Ecol Lett 14:101-112. https ://doi.org/10.1111/j.1461-0248.2010.01559.x

Fournier E, Loreau M (2001) Respective roles of recent hedges and forest patch remnants in the maintenance of ground-beetle (Coleoptera: Carabidae) diversity in an agricultural landscape. Landsc Ecol 16:17-32. https://doi.org/10.1023/A:1008115516551

Fox J, Weisberg S (2010) Nonlinear regression and nonlinear least squares. R: an appendix to an R companion to applied regression. SAGE, Thousand Oaks

Gagic V, Kleijn D, Báldi A, Boros G, Jørgensen HB, Elek Z et al (2017) Combined effects of agrochemicals and ecosystem services on crop yield across Europe. Ecol Lett 20:1427-1436. https://doi. org/10.1111/ele.12850

Gallé R, Császár P, Makra T, Gallé-Szpisjak N, Ladányi Z, Torma A et al (2018) Small-scale agricultural landscapes promote spider and ground beetle densities by offering suitable overwintering sites. Landsc Ecol 33:1435-1446. https://doi.org/10.1007/s1098 0-018-0677-1

Gallé R, Happe AK, Baillod AB, Tscharntke T, Batáry P (2019) Landscape configuration, organic management and within-field position drive functional diversity of spiders and carabids. J Appl Ecol 56:63-72. https://doi.org/10.1111/1365-2664.13257

Gámez-Virués S, Perović DJ, Gossner MM, Börschig C, Blüthgen N, De Jong $\mathrm{H}$ et al (2015) Landscape simplification filters species traits and drives biotic homogenization. Nat Commun 6:8568. https://doi.org/10.1038/ncomms9568

Greenstone MH (1999) Spider predation: how and why we study it. J Arachnol 27:333-342

Heimer S, Nentwig W (1991) Spinnen mitteleuropas - ein bestimmungsbuch. Verlag Paul Parey, Berlin und Hamburg

Hendrickx F, Maelfait JP, van Wingerden W, Schweiger O, Speelmans M, Aviron S et al (2007) How landscape structure, land-use intensity and habitat diversity affect components of total arthropod diversity in agricultural landscapes. J Appl Ecol 44:340-351. https ://doi.org/10.1111/j.1365-2664.2006.01270.x

Hole DG, Perkins AJ, Wilson JD, Alexander IH, Grice PV, Evans AD (2005) Does organic farming benefit biodiversity? Biol Conserv 122:113-130. https://doi.org/10.1016/j.biocon.2004.07.018

Holland JM, Thomas CFG, Birkett T, Southway S (2007) Spatiotemporal distribution and emergence of beetles in arable fields in relation to soil moisture. Bull Entomol Res 97:89-100. https:// doi.org/10.1017/S0007485307004804

Honczarenko J (1975) An influence of high-dose nitrogen fertilizer on the entomofauna of meadow soil. Pedobiologia 16:58-62 (in Russian, with English summary)

Hůrka K (1996) Carabidae of the Czech and Slovak Republics. Kabourek, Zlín

Kiss B, Samu F (2000) Evaluation of population densities of the common wolf spider Pardosa agrestis (Araneae: Lycosidae) in Hungarian alfalfa fields using mark-recapture. Eur J Entomol 97:191-196. https://doi.org/10.14411/eje.2000.036

Knapp M, Seidl M, Knappová J, Macek M, Saska P (2019) Temporal changes in the spatial distribution of carabid beetles around arable field-woodlot boundaries. Sci Rep 9:8967. https://doi.org/10.1038/ s41598-019-45378-7

Kleijn D, Kohler F, Báldi A, Batáry P, Concepción ED, Clough Y et al (2009) On the relationship between farmland biodiversity and land-use intensity in Europe. Proc R Soc B 276:903-909. https:// doi.org/10.1098/rspb.2008.1509

Kleijn D, Bommarco R, Fijen TPM, Garibaldi LA, Potts SG, van der Putten WH (2019) Ecological intensification: bridging the gap between science and practice. Trends Ecol Evol 34:154-166. https ://doi.org/10.1016/j.tree.2018.11.002

Kovács-Hostyánszki A, Kőrösi Á, Orci KM, Batáry P, Báldi A (2011) Set-aside promotes insect and plant diversity in a Central European country. Agric Ecosyst Environ 141:296-301. https://doi. org/10.1016/j.agee.2011.03.004

Kovács-Hostyánszki A, Báldi A (2012) Set-aside fields in agri-environment schemes can replace the market-driven abolishment of fallows. Biol Conserv 152:196-203. https://doi.org/10.1016/j. biocon.2012.03.039

Kromp B (1999) Carabid beetles in sustainable agriculture: a review on pest control efficacy, cultivation impacts and enhancement. Agric Ecosyst Environ 74:187-228. https://doi.org/10.1016/S0167 -8809(99)00037-7

Kuperman RG (1996) Relationships between soil properties and community structure of soil macroinvertebrates in oak-hickory forests along an acidic deposition gradient. App Soil Ecol 4:125-137. https://doi.org/10.1016/0929-1393(96)00108-4

Landis DA, Wratten SD, Gurr GM (2000) Habitat management to conserve natural enemies of arthropod pests in agriculture. Annu Rev Entomol 45:175-201. https://doi.org/10.1146/annurev.ento.45.1.175

Loksa I (1969) Araneae I. Fauna Hungariae 97. Akadémiai Kiadó, Budapest

Loksa I (1972) Araneae II. Fauna Hungariae 109. Akadémiai Kiadó, Budapest 
Lövei GL (2005) Generalised entropy indices have a long history in ecology - a comment. Commun Ecol 6:245-247. https://doi. org/10.1556/ComEc.6.2005.2.13

Luff ML, Rushton SP (1989) The ground beetle and spider fauna of managed and unimproved upland pasture. Agric Ecosyst Environ 25:195-205. https://doi.org/10.1016/0167-8809(89)90051-0

Mader V, Diehl E, Wolters V, Birkhofer K (2018) Agri-environmental schemes affect the trophic niche size and diet of common carabid species in agricultural landscapes. Ecol Entomol 43:823-835. https://doi.org/10.1111/een.12671

Madeira F, Pons X (2016) Rubidium marking reveals different patterns of movement in four ground beetle species (Col., Carabidae) between adjacent alfalfa and maize. Agric Forest Entomol 18:99-107. https://doi.org/10.1111/afe.12141

Madeira F, Tscharntke T, Elek Z, Kormann UG, Pons X, Rösch V et al (2016) Spillover of arthropods from cropland to protected calcareous grassland - the neighbouring habitat matters. Agric Ecosyst Environ 235:127-133. https://doi.org/10.1016/j.agee.2016.10.012

Magura T, Lövei GL (2019) Environmental filtering is the main assembly rule of ground beetles in the forest and its edge but not in the adjacent grassland. Insect Sci 26:154-163. https://doi. org/10.1111/1744-7917.12504

Martin EA, Dainese M, Clough Y, Báldi A, Bommarco R, Gagic V et al (2019) The interplay of landscape composition and configuration: new pathways to manage functional biodiversity and agroecosystem services across Europe. Ecol Lett. https://doi.org/10.1111/ ele. 13265

Mason BJ (1983) Preparation of soil sampling protocols: techniques and strategies, EPA-600/4-83-020. Environmental Monitoring and Support Laboratory. U.S. Environmental Protection Agency, Las Vegas

Mauremooto JR, Wratten SD, Worner SP, Fry GLA (1995) Permeability of hedgerows to predatory carabid beetles. Agric Ecosyst Environ 52:141-148. https://doi.org/10.1016/0167-8809(94)00548-S

Mestre L, Schirmel J, Hetz J, Kolb S, Pfister SC, Amato M et al (2018) Both woody and herbaceous semi-natural habitats are essential for spider overwintering in European farmland. Agric Ecosyst Environ 267:141-146. https://doi.org/10.1016/j.agee.2018.08.018

Nentwig W, Blick T, Gloor D, Hänggi A, Kropf C (2019) Araneae Spiders of Europe. https://www.araneae.nmbe.ch. Accessed 20 June 2019

Nietupski M, Sowinsk P, Sądej W, Kosewska A (2010) Content of organic $\mathrm{C}$ and $\mathrm{pH}$ of bog and post-bog soils versus the presence of ground beetles Carabidae in Stary Dwor near Olsztyn. J Elementol 15:581-591. https://doi.org/10.5601/jelem.2010.15.3..581-591

Oksanen J, Blanchet FG, Friendly M, Kindt R, Legendre P, McGlinn D et al (2017) Vegan: community ecology package. https://CRAN.Rproject.org/package=vegan. Accessed 15 Sept 2017

Olden JD, Poff NL, Douglas MR, Douglas ME, Fausch KD (2004) Ecological and evolutionary consequences of biotic homogenization. Agric Ecosyst Environ 19:18-24. https://doi.org/10.1016/j. tree.2003.09.010

Pakeman RJ, Stockan JA (2014) Drivers of carabid functional diversity: abiotic environment, plant functional traits, or plant functional diversity? Ecology 95:1213-1224. https://doi. org/10.1890/13-1059.1

Pfiffner L, Luka H (2000) Overwintering of arthropods in soils of arable fields and adjacent semi-natural habitats. Agric Ecosyst Environ 78:215-222. https://doi.org/10.1016/S0167-8809(99)00130-9

Pinheiro J, Bates D, DebRoy S, Sarkar D, R Core Team (2017) Nlme: linear and nonlinear mixed effects models. https://CRAN.R-proje ct.org/package=nlme. Accessed 15 Sept 2017

R Core Team (2017) R: a language and environment for statistical computing. $\mathrm{R}$ foundation for statistical computing, Vienna, Austria. https://www.R-project.org. Accessed 18 Aug 2017
Rand TA, Tylianakis JM, Tscharntke T (2006) Spillover edge effects: the dispersal of agriculturally subsidized insect natural enemies into adjacent natural habitats. Ecol Lett 9:603-614. https://doi.org /10.1111/j.1461-0248.2006.00911.x

Ricotta C (2005) On parametric diversity indices in ecology: a historical note. Commun Ecol 6:241-244. https://doi.org/10.1556/ ComEc.6.2005.2.12

Sądej W, Sądej W, Rozmyslowicz R (2008) Soil concentration of C and $\mathrm{N}$ shaped by long-term unidirectional fertilization versus noxious soil macrofauna. J Elementol 13:381-389

Sądej W, Kosewska A, Sądej W, Nietupski M (2012) Effects of fertilizer and land-use type on soil properties and ground beetle communities. Bull Insectol 65:239-246

Samu F, Szinetár C (2002) On the nature of agrobiont spiders. J Arachnol 30:389-402. https://doi.org/10.1636/0161-8202(2002)030

Schellhorn NA, Bianchi FJJA, Hsu CL (2014) Movement of entomophagous arthropods in agricultural landscapes: links to pest suppression. Annu Rev Entomol 59:559-581. https://doi. org/10.1146/annurev-ento-011613-161952

Scheu S (2001) Plants and generalist predators as links between the below-ground and above-ground system. Basic Appl Ecol 2:3-13. https://doi.org/10.1078/1439-1791-00031

Schmidt-Entling MH, Döbeli J (2009) Sown wildflower areas to enhance spiders in arable fields. Agric Ecosyst Environ 133:1922. https://doi.org/10.1016/j.agee.2009.04.015

Siemann E (1998) Experimental tests of effects of plant productivity and diversity on grassland arthropod diversity. Ecology 79:20572070. https://doi.org/10.1890/0012-9658(1998)079[2057:ETOEO P]2.0.CO;2

Strobl C, Boulesteix A, Kneib T, Augustin T, Zeileis A (2008) Conditional Variable importance for random forests. http://www.biome dcentral.com/1471-2105/9/307. Accessed 15 Sept 2017

Tamburini G, De Simone S, Figura M, Boscutti F, Marini L (2016) Soil management shapes ecosystem service provision and trade-offs in agricultural landscapes. Proc R Soc B 283:20161369. https://doi. org/10.1098/rspb.2016.1369

Tóth ZS, Hornung E, Báldi A (2018) Effects of set-aside management on certain elements of soil biota and early stage organic matter decomposition in a high nature value area, Hungary. Nat Conserv 29:1-26. https://doi.org/10.3897/natureconservation.29.24856

Tóthmérész B (1995) Comparison of different methods for diversity ordering. J Veg Sci 6:283-290. https://doi.org/10.2307/3236223

Tscharntke T, Batáry P, Dormann CF (2011) Set-aside management: How do succession, sowing patterns and landscape context affect biodiversity? Agric Ecosyst Environ 143:37-44. https://doi. org/10.1016/j.agee.2010.11.025

Tscharntke T, Karp DS, Chaplin-Kramer R, Batáry P, DeClerck F, Gratton $C$ et al (2016) When natural habitat fails to enhance biological pest control - five hypotheses. Biol Conserv 204:449-458. https://doi.org/10.1016/j.biocon.2016.10.001

Tscharntke T, Rand TA, Bianchi FJ (2005) The landscape context of trophic interactions: insect spillover across the crop-noncrop interface. Ann Zool Fenn 42:421-432

Tscharntke T, Tylianakis JM, Rand TA, Didham RK, Fahrig L, Batáry $P$ et al (2012) Landscape moderation of biodiversity patterns and processes-eight hypotheses. Biol Rev 87:661-685. https://doi. org/10.1111/j.1469-185X.2011.00216.x

Uetz GW, Halaj J, Cady AB (1999) Guild structure of spiders in major crops. J Arachnol 27:270-280

Zadoks JC, Chang TT, Konzak CF (1974) A decimal code for the growth stages of cereals. Weed Res 14:415-421. https://doi. org/10.1111/j.1365-3180.1974.tb01084.x

Publisher's Note Springer Nature remains neutral with regard to jurisdictional claims in published maps and institutional affiliations. 